\title{
ANALISA KEPADATAN DAN IDENTIFIKASI AKTIVITAS PEMANFAATAN SUMBERDAYA MOLUSKA DI PERAIRAN PANTAI TANJUNG TIRAM, DESA POKA
}

\section{(Density Analyze and Identification of Utilization Activity of Mollusc Resources at Tanjung Tiram Waters, Poka Village)}

\author{
Mahriyana Hulopi ${ }^{1 *}$, Sendy W. Mose $^{2}$ dan Prulley A. Uneputty ${ }^{1}$ \\ ${ }^{1}$ Jurusan Manajemen Sumberdaya Perairan Fakultas Perikanan dan Ilmu Kelautan Universitas Pattimura \\ ${ }^{2}$ Mahasiswa Program Studi Manajemen Sumberdaya Perairan Fakultas Perikanan dan Ilmu Kelautan \\ Universitas Pattimura \\ mhulopi75@gmail.com,sendymose96@gmail.com,nonnyune@gmail.com \\ Corresponding author*
}

\begin{abstract}
ABSTRAK: Meningkatnya aktivitas pemanfaatan sumberdaya moluska oleh masyarakat, baik yang berdomisili di sekitar maupun di luar perairan Pantai Tanjung Tiram dapat berdampak terhadap keberlanjutan sumberdaya tersebut. Penelitian ini bertujuan untuk menganalisis kepadatan moluska serta mengidentifikasi aktivitas pemanfaatan sumberdaya moluska di perairan Pantai Tanjung Tiram. Penelitian dilakukan pada Oktober-November 2019 di perairan Pantai Tanjung Tiram Desa Poka. Pengumpulan data dilakukan dengan menggunakan metode transek linier kuadrat dan wawancara. Hasil penelitian menunjukkan densitas tertinggi diwakili oleh Nassarius quadrasi untuk kelas gastropoda sedangkan untuk kelas bivalvia diwakili oleh Marcia sp. Tingginya densitas pada kedua jenis moluska ini disebabkan oleh kesesuaian habitat yang didukung oleh kualitas perairan. Berdasarkan data responden, terdapat 20 jenis moluska yang dimanfaatkan baik untuk dikonsumsi, di jual maupun sebagai bahan baku pembuatan aksesoris melalui aktivitas "bameti". Aktivitas pemanfaatan dilakukan oleh kelompok perempuan dan anak-anak. Waktu pengambilan moluska dilakukan pada saat air surut yang berlangsung 2 kali dalam seminggu dengan menggunakan alat bantu seperti tempurung kelapa, sendok, serok dan parang.
\end{abstract}

Kata Kunci: kepadatan, aktivitas pemanfaatan, moluska, "bameti”, perairan Pantai Tanjung Tiram

\begin{abstract}
Increasing the activity of the utilization of mollusc resources by the community, both domiciled around and outside the waters of Tanjung Tiram Beach can have an impact on the sustainability of these resources. This study aims to analyze the density of mollusc and identify the activity of utilization of mollusc resources in the waters of Tanjung Tiram Beach. The study was conducted in October-November 2019 in the waters of Tanjung Tiram Beach, Poka Village. Data collection is taken using the quadratic linear transect method and interviews. The results showed the highest density was represented by Nassarius quadrasi for the gastropod class while for the bivalvia class it was represented by Marcia $s p$. The high density in both types of mollusc is due to habitat suitability supported by the quality of the waters. Based on respondent data, there are 20 types of mollusc that are used both for consumption, sale and as raw materials for making accessories through the "bameti" activity. Utilization activities are carried out by groups of women and children. The time of taking mollusks is done at low tide which takes place 2 times a week using aids such as coconut shells, spoons, drain and machetes.
\end{abstract}


Keywords: density, utilization activity, mollusc, "bameti", waters of Tanjung Tiram Beach

\section{PENDAHULUAN}

Kawasan pesisir dan laut memegang peranan penting bagi kesejahteraan masyarakat (Teja, 2015; Dwwi, 2018). Kawasan pesisir dan laut memiliki nilai strategis berupa potensi sumberdaya alam dan jasa-jasa lingkungan yang dapat dimanfaatkan bagi pemenuhan hidup masyarakat dan bagi pengembangan eknomi nasional (Hartanto, 2011; Marasabessy, $d k k$. 2018). Sebagai wilayah tropik, perairan pesisir dan laut Indonesia mempunyai keanekaragaman hayati yang cukup tinggi seperti hutan mangrove, padang lamun, terumbu karang, ikan, mamalia, reptilia dan berbagai jenis moluska (Karimah, 2017; Muzani, dkk., 2020). Fakta tentang wilayah pesisir dan laut memberikan konsekuensi logis bahwa potensi sumberdaya pesisir dan laut dapat menjadi tumpuan hidup bagi masyarakat khususnya yang berdomisili di sekitar wilayah pesisir.

Moluska, merupakan salah satu sumberdaya pesisir yang sejak lama telah dimanfaatkan oleh masyarakat (Islami, $d k k$, 2018). Bagian tubuh moluska yang umumnya dimanfaatkan adalah daging sebagai sumber protein hewani (Supusepa, 2018) dan cangkang digunakan sebagai bahan baku dalam industri dan perhiasan (Setiawan, $d k k$., 2019).

Pesisir Pantai Tanjung Tiram merupakan wilayah yang cukup kompleks dengan berbagai permasalahan karena berdekatan dengan pemukiman penduduk dan adanya berbagai aktivitas pemanfaatan (Tupan\&Wawo, 2019) seperti tempat penambatan perahu, pembuangan sampah, dan pengambilan sumberdaya laut seperti moluska, ikan, teripang dan bulu babi. Aktivitas pengambilan sumberdaya pesisir dan laut yang dilakukan saat air surut di wilayah perairan Maluku dikenal dengan istilah "bameti" (Sitaniapessy, 2016: Siahainenia, $d k k$., 2017). Salah satu sumberdaya yang menjadi target yaitu moluska atau dikenal dengan "bia". Seiring dengan meningkatnya kebutuhan masyarakat akan sumber protein hewani, semakin meningkat pula aktivitas pemanfaatan sumberdaya pesisir dan laut khususnya pemanfaatan moluska di sekitar pantai Tanjung Tiram sehingga mengakibatkan terjadinya penurunan populasi moluska dari waktu ke waktu (Wawo\&Uneputty, 2013). Penurunan sumberdaya moluska juga diakibatkan oleh kerusakan habitat. Rusaknya habitat moluska diakibatkan oleh banyaknya sampah yang menutupi substrat, penurunan komunitas mangrove akibat penebangan pohon mangrove (Candri, $d k k$., 2020), rusaknya padang lamun (Istiqlal, $d k k$., 2013). Selain itu, kerusakan pada lingkungan juga dapat diakibatkan oleh cara pengambilan moluska, lama waktu pengambilan dan penggunaan alat yang tidak ramah lingkungan (Lopuhaa, 2014). Sumberdaya moluska yang dimanfaatkan harus dapat dikelola dengan tepat dan berkelanjutan sehingga ekosistem pesisir dan laut tetap terjaga. Tujuan dari penelitian ini adalah untuk menganalisis kepadatan moluska serta mengidentifikasi aktivitas pemanfaatan sumberdaya moluska pada perairan Pantai Tanjung Tiram, Desa Poka.

\section{METODE PENELITIAN}

Penelitian ini dilakukan pada bulan Oktober-November 2018 yang berlokasi pada perairan Pantai Tanjung Tiram, Desa Poka, Kecamatan Teluk Ambon (Gambar 1). Pengambilan data moluska dilakukan pada saat air surut dengan menggunakan metode transek linier kuadrat (Loya, 1978). Sampel moluska yang ditemukan dimasukkan ke kantong plastik untuk diidentifikasi dengan berpedoman pada buku identifikasi menurut Dance (1974), Dharma (1988, 1992), Wilson, et al. (1994), dan Wye (2000). Pengambilan data aktivitas masyarakat dengan menggunakan metode wawancara dengan masyarakat yang bermukim dan beraktivitas di sekitar perairan Pantai Tanjung Tiram.

Teknik penentuan responden dilakukan dengan menggunakan rumus linier time function (Sari, 1998) dengan jumlah responden ditentukan berdasarkan waktu efektif yang digunakan untuk 
penelitian. Dalam penelitian ini, waktu yang digunakan adalah 7 hari dalam 1 minggu. Waktu yang digunakan untuk wawancara dalam sehari diperkirakan 1 jam karena merupakan waktu yang efektif untuk mengumpulkan data serta disesuaikan dengan air pasang.

Keterangan:

$$
n=\frac{T-t_{0}}{t_{1}}
$$

$\mathrm{n}=$ Jumlah responden (24 responden)

$\mathrm{T}=$ Waktu penelitian 7 hari $(1$ jam $\times 60$ menit $\times 7$ hari $=420$ )

$\mathrm{t}_{0} \quad=$ Periode waktu harian $(1$ jam $\mathrm{x} 60$ menit $=60$ )

$\mathrm{t}_{1}=$ Waktu pengisian kuisioner $(15$ menit $)$

Analisa data kepadatan moluska dapat dihitung dengan menggunakan rumus menurut Odum (1994), sedangkan aktivitas masyarakat dianalisa secara deskriptif.

Desintas $\left(\frac{\text { ind }}{m^{2}}\right)=\frac{\text { Jumlah indovidu suatu jenis }}{\text { Luas plot contoh }}$

\section{HASIL DAN PEMBAHASAN}

Berdasarkan hasil penelitian diperoleh sumberdaya moluska di perairan Pantai Tanjung Tiram Desa Poka (Tabel 1), untuk kelas gastropoda sebanyak 25 spesies yang terdiri atas 5 Ordo, 12 Famili, dan 14 Genera. Kelas bivalvia terdiri atas 2 Ordo, 6 Famili, dan 8 Genera sebanyak 10 spesies. Spesies moluska yang paling banyak ditemukan berasal dari famili Nassaridae, namun terdapat pula spesies dengan jumlah individu terendah. Hal ini disebabkan oleh beberapa faktor seperti ketidaksesuaian dengan habitat, serta makanan yang juga mempengaruhi komposisi spesies pada tiap lokasi. Menurut Dewi, $d k k$, (2019) menyatakan bahwa jika pada suatu habitat dihuni oleh spesies dalam jumlah yang sedikit maka kompetisi dalam memperebutkan ruang dan nutrisi akan semakin kecil sehingga spesies akan berkembang biak dengan baik dan sebaliknya. Selain itu, pemanfaatan berlebih mengakibatkan berkurangnya spesies-spesies tertentu (Ranti, 2011).

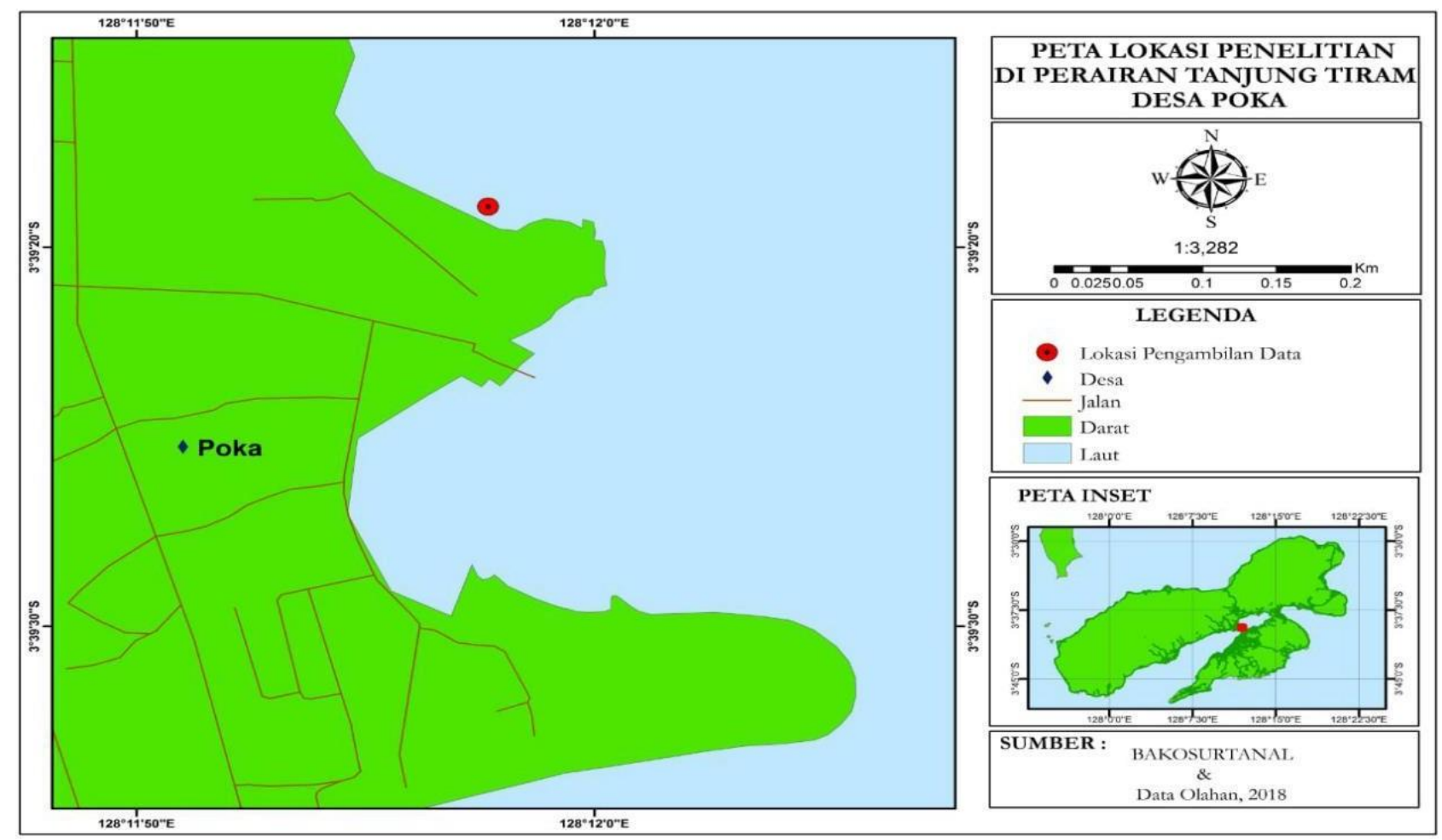

Gambar 1. Peta Lokasi Penelitian 
Tabel 1. Komposisi jenis moluska yang ditemukan pada perairan Pantai Tanjung Tiram

\begin{tabular}{|c|c|c|c|c|c|}
\hline Kelas & Order & Famili & Genus & Spesies & Jumlah Individu \\
\hline \multirow{25}{*}{ Gastropoda } & Cephalaspidea & Bullidae & Bulla & B. ampulla & 1 \\
\hline & Neogastropoda & Pisaniidae & Cantharus & C. crythrostomus & 2 \\
\hline & & Conidae & Conus & C. corronatus & 1 \\
\hline & & & & C. lividus & 1 \\
\hline & & & & C. sugillatus & 1 \\
\hline & & Muricidae & Cronia & C. crassulnata & 36 \\
\hline & & & Morula & M. margariticola & 1 \\
\hline & & Nassaridae & Nassarius & N. castus & 1 \\
\hline & & & & N. globosus & 18 \\
\hline & & & & N. luridus & 1 \\
\hline & & & & N. quadrasi & 166 \\
\hline & & & & N. spendidulus & 3 \\
\hline & & & & N. sufflatus & 1 \\
\hline & Caenogastropoda & Cerithiidae & Clypeomorus & C. moniliferus & 2 \\
\hline & Hypsogastropoda & Cymatiidae & Cymatium & C.muricinum & 1 \\
\hline & & Littorinidae & Littorina & L. irrorata & 1 \\
\hline & & Naticidae & Notocochlis & N. guatteriana & 2 \\
\hline & & & Polinices & P. mammila & 5 \\
\hline & Mesogastropoda & Cypraeidae & Cypraea & C. anullus & 36 \\
\hline & & & & C. errones & 1 \\
\hline & & & & C. ovum & 6 \\
\hline & & Neritidae & Nerita & N. chamaeleon & 10 \\
\hline & & & & N. signata & 3 \\
\hline & & Strombidae & Strombus & S. microurceus & 15 \\
\hline & & & & S. urceus & 7 \\
\hline \multirow{10}{*}{ Bivalvia } & Arcoida & Arcidae & Anadara & A.antiquata & 19 \\
\hline & Veneroida & Veneridae & Circe & C. scripta & 2 \\
\hline & & & Gafrarium & G. pectinatum & 7 \\
\hline & & & & G.tumidum & 13 \\
\hline & & & Marcia & M. hiantina & 6 \\
\hline & & & & M. sp. & 24 \\
\hline & & Psammobiidae & Hiatula & H.chinensis & 23 \\
\hline & & Mactridae & Mactra & M. gianca & $\begin{array}{l}23 \\
4\end{array}$ \\
\hline & & Semelidae & Smele & S. $s p$ & $\begin{array}{l}4 \\
7\end{array}$ \\
\hline & & Cardiidae & Trachycardium & T. orbita & 16 \\
\hline
\end{tabular}

Densitas tertinggi untuk kelas gastropoda diwakili spesies Nassarius quadrasi, dengan nilai $10.22 \mathrm{ind} / \mathrm{m} 2$, sedangkan nilai densitas terendah ditemukan pada 21 spesies gastropoda lainnya dengan kisaran nilai $0.06-0.92 \mathrm{ind} / \mathrm{m}^{2}$. Pada kelas bivalvia, spesies dengan nilai densitas tertinggi yaitu Marcia sp. sebesar 1.48 ind/m2, sedangkan 7 spesies bivalvia lainnya memiliki nilai densitas yang cukup rendah, yaitu berkisar $0.8-0.98 \mathrm{ind} / \mathrm{m}^{2}$.

Berdasarkan hasil wawancara, tingginya nilai densitas spesies Nassarius quadrasi dikarenakan spesies ini merupakan salah satu spesies yang tidak dimanfaatkan oleh para pelaku pemanfaat sumberdaya moluska. Selain itu, Kelas Gastropoda Famili Nassaridae sering dijumpai pada daerah intertidak dan sublittoral serta merupakan hewan aktif (Rahmasari, $d k k$., 2015). Kepadatan sutau spesies di suatu habitat juga dipengaruhi oleh kualitas perairan. Berdasarkan hasil pengukuran diketahui bahwa kualitas perairan meliputi suhu, salinitas dan kondisi substrat sangat mendukung keberadaan spesies ini di Pantai Tajung Tiram Desa Poka. Berdasarkan hasil penelitian di Perairan Semarang (Kharisma, $d k k$., 2012) diperoleh bahwa Genus Anadara dan Genus Marcia menunjukkan pola sebaran yang mengelompok. Hal ini ditunjang oleh sifat moluska yang hidupnya bergerombol, seragam dan menempel pada habitat sepanjang waktu. Kelas Bivalvia dengan jumlah individu terbanyak yaitu jenis 
Marcia sp. Hal ini disebabkan substrat Pantai Tanjung Tiram yang memiliki ekosistem mangrove serta lamun cenderung berpasir dan berlumpur, terdapat juga kerikil (Tupan\&Wawo, 2019). Substrat ini sesuai dengan kelas Bivalvia Famili Veneridae. Penelitian Sitompul (2020) juga membuktikan bahwa beberapa spesies yang termasuk dalam Famili Veneridae dapat hidup pada daerah intertidak dan sublittoral hingga kedalaman 30 meter, sehingga kegiatan "bameti" yang dilakukan oleh masyarakat tidak menjangkau area tersebut. Sedangkan spesiesspesies dengan densitas yang rendah dapat disebabkan karena adanya pungut lebih, ketidakcocokan dengan habitat juga pemangsaan yang turut menyebabkan terjadinya penurunan populasi moluska dan menjadi salah satu ancaman. Tindakan pungut lebih artinya pemanfaatan sumberdaya moluska telah berada dalam kondisi over exploitation. Berdasarkan hasil penelitian Sairlela (2008), tingkat pemanfaatan terhadap sumberdaya moluska di Desa Waiheru Teluk Ambon Dalam mencapai $30.720 \mathrm{ind} /$ tahun, sedangkan yang diijinkan yaitu hanya $2.837,45 \mathrm{ind} /$ tahun.

Berdasarkan hasil penelitian teridentifikasi aktivitas pemanfaatan terhadap sumberdaya moluska di perairan Pantai Tanjung Tiram yaitu aktivitas "bameti" (Gambar 2). Aktivitas "bameti" telah dilakukan sejak lama dan merupakan tradisi masyarakat yang hidup di pesisir Maluku. Pelaku pemanfaat sumberdaya moluska pada perairan Tanjung Tiram bukan saja masyarakat yang bermukim pada daerah pesisir tersebut, tetapi ada juga yang berasal dari luar (Wayame, Wailela dan Kampung Keranjang). Berdasarkan hasil penelitian (Wawo\&Uneputty, 2013) diperoleh bhawa aktivitas "bameti" dijumpai di wilayah pesisir Desa Poka dan Desa Waiheru. Aktivitas "bameti" ini melibatkan perempuan dan anak-anak. Umumnya masyarakat memanfaatkan sumberdaya tersebut untuk konsumsi, terlebih bila harga ikan atau makanan lainnya di pasar sedang melonjak, serta ada juga yang dijual untuk memenuhi kebutuhan hidup.

Berdasarkan hasil wawancara diperoleh bahwa jenis alat yang digunakan saat "bameti" antara lain tempurung kelapa, sendok, serok dan parang. Dampak pengabilan moluska menggunakan beberapa alat tersebut mempengaruhi keberadaan moluska dan ekosistem lamun sebagai habitatnya. Sebaliknya, pengambilan sumberdaya moluska dengan cara memungut satu per satu tidak akan memberikan dampak yang terlalu berpengaruh negatif, seperti pernyataan Hartono, $d k k$. (2005) bahwa semakin tinggi intensitas pelaku pemanfaatan dengan cara memungut, maka akan mengurangi ancaman terhadap keberlanjutan sumberdaya moluska dan ekosistem lamun.

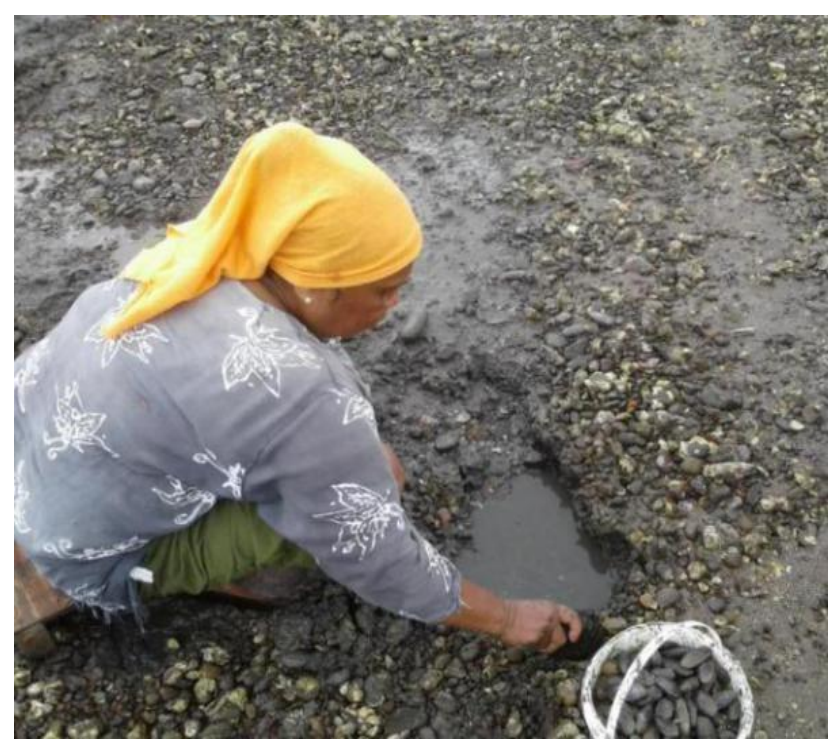

Gambar 2. Aktivitas "bameti" di Tanjung Tiram

Berdasarkan hasil wawancara terhadap responden mengenai waktu dalam kegiatan pemanfaatan sumberdaya moluska, didapati bahwa waktu yang digunakan untuk melakukan kegiatan "bameti" tidak menentu. Hal ini disebabkan aktivitas tersebut bergantung pada surutnya air laut. Aktivitas pemanfaatan moluska ini juga umumnya dilakukan 2 kali dalam seminggu pada saat air surut. Tujuan Masyarakat yang ingin memanfaatkan sumberdaya moluska hanya sebagai konsumsi yang dilakukan pada waktu tertentu, akan lebih jarang melakukan aktivitas "bameti", (umumnya dilakukan hanya satu kali dalam 1-2 bulan).

Spesies-spesies moluska di Pantai Tanjung Tiram Desa Poka yang dimanfaatkan untuk konsumsi adalah Polinices mammilla, Littorina irrorata, Circe scripta, Hiatula chinensis, Trachycardium orbita, Marcia sp., Anadara antiquata, Gafrarium pectinatum, Gafrarium 
tumidium, Mactra gianta, Smele sp. dan Marcia hiantina. Sedangkan untuk jenis yang dimanfaatkan untuk bahan baku pembuatan aksesoris adalah Nerita chamaleon, Conus lividus, Cypraea anullus, Strombus microureus, Nassarius sufflatus, Conus corronatus, Bulla ampulla, Cypraea ovum dan Cymatium muricinum.

\section{KESIMPULAN DAN SARAN}

Berdasarkan hasil penelitian maka dapat disimpulkan, pertama densitas tertinggi untuk kelas gastropoda diwakili spesies Nassarius quadrasi, sedangkan untuk kelas Bivalvia diwakili oleh Marcia sp. Kedua, aktivitas pemanfaatan sumberdaya moluska yang dilakukan oleh masyarakat yaitu "bameti" yang dilakukan saat air surut, umumnya dilakukan 2 kali dalam seminggu. Jenis alat yang digunakan saat "bameti" antara lain tempurung kelapa, sendok, serok dan parang. Adapun saran yang dapat diberikan yaitu perlu direkomendasikan suatu arahan pengelolaan guna keberlanjutan sumberdaya moluska dan habitanya.

\section{DAFTAR PUSTAKA}

Candri, D.A., L.H. Sani, H. Ahyadi, B. Farista. 2020. Struktur Komunitas Moluska di Kawasan Mangrove Alami dan Rehabilitasi Pesisir Selatan Pulau Lombok. Jurnal Biologi Tropis 20(1): 139-147. DOI: 10.29303/jbt.v20i1.1385.

Dance, S, P. 1974. The Collector's Encyclopedia of Shells. New Jersey. Cartwell Books Inc : 203 pp.

Dewi, A.A. 2018. Model Pengelolaan Wilayah Pesisir Berbasis Masyarakat: Community Based Management. Jurnal Penelitian Hukum De Jure 18(2): 163-182. http://dx.doi.org/10.30641/dejure.2018.V18.1 63-182.

Dewi, A.NM., Jelantik, S.IB, Budi A.P. 2019. Studi Tentang Keanekaragaman dan Kemelimpahan Mollusca Bentik Serta Faktor-Faktor Ekologis yang Mempengaruhinya di Pantai Mengening, Kabupaten Badung, Bali. Jurnal Pendidikan Biologi Undiksha 6(3): 146-156.

Dharma, B. 1988. Siput dan Kerang Indonesia I. Sarana Graha. Jakarta.
Dharma, B. 1992. Siput dan Kerang Indonesia II. Sarana Graha. Jakarta.

Hartanto, B. Pengelolaan Ekosistem di Wilayah Pesisir dan Laut Secara Terpadu. BAHARI Jogja XI(19): 22-46.

Hartono, T. T., T. Kodira, M. A. Iqbal dan Sonny, K. 2005. Pengembangan Teknik Rapid Appraisal for Fisheries (RAPFISH) untuk Penentuan Indikator Kinerja Perikanan Tangkap Berkelanjutan di Indonesia. Buletin Ekonomi Perikanan. 6(1): .65-76.

Islami, M.M., I. Y. Ikhsani, T. Indrabudi, I. A.H. Pelupessy. 2018. Komposisi Jenis, Keanekaragaman, dan Pemanfaatan Moluska di Pesisir Pulau Saparua, Maluku Tengah. Widyariset 4(2): 173-188.

Istiqlal, B.A., D. S. Yusuf, N.M. Suartini. 2013. Distribusi Horizontal Moluska di Kawasan Padang Lamun Pantai Merta Segara Sanur, Denpasar. Jurnal Biologi XVII(1): 10-14.

Karimah. 2017. Peran Ekosistem hutan Mangrove Sebagai Habitat Untuk Organisme Laut. Jurnal Biologi Tropis 17(2): 51-58.

Kharisma, D., Chrisna A.S, Ria A.T.N. 2012. Kajian Ekologis Bivalvia di Perairan Semarang Bagian Timur Pada Bulan Maret-April 2012. Journal of Marine Research 1(2): 216-225.

Lopuhaa, S. 2014. Studi Sumberdaya Gastropoda Pada Tipe Substrat Berbeda di Desa Suli, Kabupaten Maluku Tengah. Skripsi. Fakultas Perikanan dan Ilmu Kelautan Unpatti. Ambon.

Loya. Y. 1978. Plotless and Transect Methods. In: Monographs on Oceanic Methodology. Coral Reefs: Research Method. DR. Stoddart, P. R dan RE. Johannes. UNESCO Press, 5 197-218.

Marasabessy, I., A. Fahrudin, Z. Imran, S.B. Agus. 2018. Strategi Pengelolaan Berkelanjutan Pesisir dan Laut Pulau Nusa Manu dan Pulau Nusa Leun di Kabupaten Maluku Tengah. Journal of Regional and Rural Development Panning 2(1): 1-22. DOI:http://dx.doi.org/10.29244/jp2wd.2018.2. 1.1-22.

Muzani, A.R. Jayanti, M.W. Wardana, N.D. Sari, Y. L. Ginting. 2020. Manfaat Padang Lamun Sebagai Penyeimbang Ekosistem Laut di Pulau Pramuka, Kepulauan Seribu. Jurnal Geografi XVIII(1): 1-14.

Odum, E. P. 1994. Dasar-Dasar Ekologi Edisi Ketiga. Universitas Gajah Mada Press. Yogyakarta.

Rahmasari, T., T. Purnomo, R. Ambarwati. 2015. Keanekaragaman dan Kelimpahan Gastropoda di Pantai Selatan Kabupaten Pamekasan, 
Madura. Biosaintifika 7(1): 8-14. DOI: 10.15294/biosaintifika.v7i1.3535.

Ranti. A. 2011. Struktur Komunitas Gastropoda pada Ekosistem Lamun di Gugus Pulau Pari, Kepulauan Seribu. Skripsi. Universitas Indonesia. Depok.

Sairlela, I. 2008. Status dan Potensi Sumberdaya Moluska Pada Ekosistem Mangrove di Perairan Desa Waiheru. Skripsi. Fakultas Perikanan dan Ilmu Kelautan Universitas Pattimura. Ambon. 53 hal.

Sari, Endang S. 1999. Audience Research. Ghalia Indonesia. Jakarta.

Setiawan, R., Sudarmadji, B.P. Mulyadi, R.H. Hamdani. 2019. Preferensi Habitat Spesies Kerang Laut (Moluska: Bivalvia) di Ekosistem Intertidal Tanjung Bilik Taman Nasional Baluran. Natural Science: Journal of Science and Technology 8(3): 165-170.

Siahainenia, L., S.F. Tuhumury, Pr. A. Uneputty, N.Chr. Tuhumury. 2017. Bentuk dan Pola Pemanfaatan Ekosistem Laguna Negeri Ihamahu, Maluku Tengah. TRITON: Jurnal Manajemen Sumberdaya Perairan 13(2): 99104.

Sitaniapessy, J. 2016. Pola Pemanfaatan dan Strategi Pengelolaan Ekosistem Mangrove di Pulau Nusalaut Kabupaten Maluku Tengah. The Journal of Fisheries Development 3(1): 17-24.
Sitompul, M.K. 2020. Identifikasi Keanekaragaman Jenis-Jenis Kerang (Bivalvia) Daerah Pasang Surut di Perairan Desa Teluk Bakau. Jurnal Manajemen Riset dan Teknologi (Jurnal Maritim) 2(1): 42-51.

Supusepa, J. 2018. Inventaris Jenis dan Potensi Gastropoda di Negeri Suli dan Negeri Tial. TRITON: Jurnal Manajemen Sumberdaya Perairan 14(1): 28-34.

Teja. M. 2015. Pembangunan untuk Kesejahteraan Masyarakat di Kawasan Pesisir. Aspirasi 6(1): 63-76.

Tupan, Ch. I. \& M. Wawo. 2019. Produksi Lamun Thalassia hemprichii di Perairan Pantai Tanjung Tiram, Poka, Teluk Ambon Dalam. Prosiding Simposium Nasional Kelautan dan Perikanan VI. Universitas Hasanudin, Makassar. 53-61 hal. ISBN 978-602-71759-69.

Wawo, M. \& Uneputty, Pr, A. 2013. Aktivitas Pemanfaatan Sumberdaya Moluska di Perairan Teluk Ambon. TRITON: Jurnal Manajemen Sumberdaya Perairan 9(2): 120-126.

Wilson, B, R., Wilson, C., dan Baker, P. 1994. Australian Marine Shells, Prosobranch Gastropods Part Two (Neogastropods). Odyssey Publishing. Australia.

Wye, K. R. 2000. The Encyclopedia of Shells. Quarto Publishing Company. London. 